\title{
Model Quantum Learning untuk Meningkatkan Hasil Belajar Pecahan
}

\author{
Wiji Astutik
}

SDN Patungrejo Kutorejo Mojokerto

Email: astutikwiji498@gmail.com

\begin{tabular}{l}
\hline Tersedia Online di \\
\hline http://www.jurnal.unublitar.ac.id/ \\
index.php/briliant \\
\hline
\end{tabular}

\begin{tabular}{l}
\hline Sejarah Artikel \\
\hline Diterima pada 31 Maret 2017 \\
Disetuji pada 4 April 2017 \\
Dipublikasikan pada 1 Mei 2017 \\
Hal. 124 -129 \\
\hline
\end{tabular}

\section{Kata Kunci:}

quantum learning, aktivitas, hasil belajar.

\begin{abstract}
Abstrak: Penelitian ini bertujuan untuk mendiskripsikan penerapan model pembelajaran Quantum Learning pada materi pecahan dapat meningkatkan aktifitas belajar dan hasil belajar siswa. Subyek penelitian sebanyak 25 siswa. Berdasarkan hasil analisis diperoleh, hasil belajar siswa yang tuntas siklus I sebanyak 14 siswa dengan ketuntasan klasikal $56 \%$ dan meningkat pada siklus II sebanyak 21 siswa ketuntasan klasikal $84 \%$. Berdasarkan hasil penelitian ini, dapat disimpulkan bahwa penerapan model pembelajaran Quantum Learning pada materi pecahan dapat meningkatkan aktifitas belajar siswa dan hasil belajar matematika siswa.
\end{abstract}

Pendidikan bagi kehidupan umat manusia merupakan kebutuhan yang harus dipenuhi sepanjang hayat. Tanpa pendidikan sama-sekali mustahil suatu kelompok manusia dapat hidup berkembang sejalan dengan aspirasi (cita-cita) untuk maju, sejahtera dan bahagia menurut konsep pandangan hidup mereka. Untuk memajukan kehidupan mereka itulah maka pendidikan menjadi sarana utama yang perlu dikelola secara sistematis dan konsisten berdasarkan berbagai pandangan teotrikal dan praktika sepanjang waktu sesuai dengan lingkungan hidup manusia itu sendiri. Pendidikan bagi bangsa indonesia saat ini merupakan kebutuhan yang harus dikembangkan sejalan dengan tuntutan pembangunan secara tahap demi tahap. Pendidikan yang dikelola dengan tertib, teratur, efektif dan efisien (berdaya guna dan berhasil) akan mampu mempercepat jalannya proses pembudayaan bangsa yang berdasarkan pokok pada penciptaan kesejahteraan umum dan pencerdasan kehidupan bangsa Indonesia, sesuai dengan tujuan nasional yang tercantum dalam alinea IV pembukaan Undang-Undang Dasar 1945 (Ihsan, Fuad, 2005, Dasar-Dasar Kependidikan, Jakarta: Rineka cipta).

Pendidikan tidaklah dipandang hanya sebagai proses mentransfer ilmu pengetahuan kepada siswa, tetapi lebih ditekankan ke arah untuk mempersiapkan mental siswa dalam mengarungi kehidupan kelak dikemudian hari agar dapat memecahkan segala persoalan yang akan dihadapi. Pendidikan juga dipengaruhi oleh proses belajar siswa. Proses belajar siswa berawal dari pengalamannya, pengkonstruksian pengetahuan, kemudian pemberian makna pada pengetahuan itu, dengan mengalami sendiri, menemukan sendiri, secara berkelompok seperti bermain, siswa menjadi senang dan lebih memahami materi pembelajaran. Pembelajaran diperlukan suatu pemusatan perhatian agar apa yang dipelajari dapat dipahami sehingga siswa dapat melakukan sesuatu yang sebelumnya tidak dapat 
dilakukannya. Di sinilah terjadi suatu perubahan kelakuan (Hamdani, 2011, Strategi Belajar Mengajar, Bandung, Pustaka Setia).

Oleh karena itu pendidikan yang diselenggarakan harus dapat memberikan bekal, sehingga siswa memiliki kemampuan dan keterampilan dalam mengikuti perkembangan ilmu pengetahuan dan teknologi. Kemampuan dan keterampilan ini membutuhkan pemikiran kritis, sistematis, logis, kreatif, serta kemampuan untuk bekerja sama dalam kerangka pembangunan ilmu pengetahuan terutama mata pelajaran matematika.

Pendidikan matematika sebagai salah satu ilmu pengetahuan merupakan salah satu sarana untuk berpikir ilmiah sehingga dapat menumbuhkan dan mengembangkan kemampuan untuk berpikir kritis, sistematis, logis dan kreatif. Ranah capaian ilmiah tersebut membawa matematika sebagai jembatan ilmu pengetahuan dan teknologi. Pendidikan matematika berperan dalam pengembangan bidang ilmu lain, baik eksakta maupun sosial. Selain itu pendidikan matematika juga diterapkan pada bidang-bidang lain dalam kehidupan sehari-hari, misal ekonomi. Berdasarkan hal tersebut semakin jelas bahwa untuk dapat lebih memahami bidang lain diperlukan penguasaan matematika.

Mengamati pendidikan di Indonesia, saat ini terdapat beberapa kendala yang dihadapi oleh tenaga pendidikan, sehingga dalam meningkatkan kualitas negara Indonesia yang bermutu juga mengalami kendala. Seperti yang terjadi pada proses pembelajaran matematika materi pecahan di SDN Payungrejo Kutorejo Mojokerto. Berdasarkan hasil pembelajaran sebagai guru kelas V SDN Payungrejo Kutorejo Mojokerto, pembelajaran matematika di kelas ternyata masih belum menunjukkan hasil sesuai yang diharapkan. Penggunaan metode ceramah disertai latihan soal yang peneliti gunakan pada pembelajaran ternyata membuat siswa hanya mendengarkan, mencatat dan mengerjakan latihan yang diberikan guru. Sehingga terkesan bahwa pembelajaran masih didominasi guru. Kelas masih berfokus pada guru sebagai sumber utama pengetahuan, dan ceramah menjadi pilihan utama dalam strategi belajar. Sebagai akibat dari hal tersebut ternyata nilai ulangan harian siswa khususnya materi pecahan menunjukkan nilai siswa masih banyak yang jauh dari KKM yang ditetapkan, dari 25 siswa terdapat 17 siswa yang tidak tuntas belajarnya sedangkan yang tuntas ada 8. Ini menunjukkan siswa mengalami kesulitan mengaplikasikan pecahan dalam kehidupan sehari-hari. Siswa juga kurang mampu dalam mengoperasikan penjumlahan dan pengurangan pada pecahan.

Untuk mengatasi permasalahan tersebut, guru sebagai fasilitator, hendaknya dapat memilih dan menggunakan suatu model pembelajaran yang banyak melibatkan siswa agar aktif dalam belajar. Selain itu suasana yang nyaman dan menyenangkan juga mempengaruhi proses belajar mengajar. Sehubungan dengan upaya untuk meningkatkan keaktifan dan semangat siswa dalam pembelajaran matematika tersebut salah satu model pembelajaran yang dapat diterapkan adalah Quantum Learning, dengan model ini siswa diajak untuk mengembangkan kerangka berpikir logis dengan menggunakan pola pikir matematis, artinya dengan pemilihan model pembelajaran ini akan mempunyai tambahan manfaat pada perkembangan pengetahuan dan pemahaman siswa terhadap konsep penting matematika. 
Peneliti merasa yakin dengan model pembelajaran Quantum Learning disebabkan model ini telah digunakan oleh Hermawan Widyastantyo (2007), yait penelitian yang dilakukan bertujuan untuk mengetahui peningkatan hasil belajar mata pelajaran IPA (SAINS) bagi siswa V Sekolah Dasar dengan menggunakan metode Quantum Learning. Hasil penelitian menunjukkan bahwa penerapan metode Quantum Learning dapat meningkatkan hasil belajar siswa pada mata pelajaran IPA (SAINS). Dengan demikian membuktikan pentingnya penerapan model pembelajaran Quantum Learning.

Disamping itu model pembelajaran Quantum Learning merupakan suatu model pembelajaran yang dapat membuat siswa langsung mengalami permasalahan, menemukan sendiri jawaban atas permasalahan dan beraktivitas sesuai dengan kompetensi yang ingin dicapai. Definisi Quantum Learning adalah interaksi-interaksi yang mengubah menjadi energi cahaya (Bobbi DePorter \& Mike Hernacki, 2011, Quantum Learning, Bandung: Kaifa, Mizan Pustaka).

Prinsip Quantum Learning adalah segalanya berbicara, segalanya bertujuan, pengalaman sebelum pemberian nama, akui setiap usaha, jika layak dipelajari maka layak pula dirayakan. Segalanya berbicara seperti halnya lingkungan kelas dan bahasa tubuh yang mengirimkan pesan untuk belajar. Segalnya bertujuan, segala sesuatu yang berhubungan dengan proses pembelajaran memiliki tujuan. Proses belajar yang paling baik terjadi ketika siswa telah mengalami informasi sebelum mereka memperoleh nama yang mereka pelajari. Ketika anak itu sudah mulai untuk belajar yang bagaimanapun untuk setiap usaha dan pekerjaan untuk belajar yang dilakukan selalu dianggap perlu dan akan berpengaruh terhadap hasil pekerjaan yang lebih baik. Apabila layak dipelajari, maka layak pula dirayakan, perayaan merupakan ungkapan kegembiraan atas keberhasilan yang diperoleh dan juga dengan perayaan dapat memberi umpan balik yang posistif. Prinsip ini dapat digunakan dalam pembelajaran matematika terutama pada materi pecahan.

\section{METODE}

Penelitian ini merupakan Penelitian Tindakan Kelas (PTK) tiap siklusnya terdiri dari empat tahap yaitu perencanaan (planning), pelaksanaan (acting), pengamatan (observating), dan refleksi (reflecting). Penelitian ini dilakukan di SDN Payungrejo Kutorejo Kabupaten Mojokerto kelas V tahun pelajaran 2015/2016. Penelitian dilaksanakan pada semester ganjil tahun pelajaran 2015/2016 dengan subjek penelitian adalah siswa kelas V sebanyak 25 siswa.

Data pada penelitian ini diperoleh dengan metode observasi dan metode tes. Observasi aktifitas siswa digunakan untuk mengamati keterlibatan siswa secara aktif selama pembelajaran dengan model Quantum Learning dan sejauh mana penerapan pembelajaran Quantum Learning yang dilakukan oleh guru. Tes yang digunakan untuk mengetahui apakah hasil belajar siswa dapat mencapai ketuntasan pada materi pecahan setelah dilakukan pembelajaran dengan model Quantum Learning.

Instrumen yang digunakan dalam penelitian ini adalah lembar observasi dan soal tes. Observasi adalah suatu kegiatan pengamatan yang meliputi kegiatan pemuatan perhatian terhadap suatu objek dengan menggunakan seluruh alat indra. (Arikunto. 2006: 156). Tes adalah serentetan pertanyaan atau latihan serta alat lain yang digunakan untuk mengukur keterampilan, pengetahuan intelegensi, 
kemampuan atau bakat yang dimiliki oleh individu atau kelompok (Arikunto, 2006:150).

Untuk menganalisis tingkat keberhasilan atau persentase keberhasilan siswa setelah proses belajar mengajar setiap siklusnya dilakukan dengan cara memberikan evaluasi berupa soal tes tertulis pada setiap akhir siklus, analisis ini dihitung dengan menggunakan statistik sederhana.

Analisis data aktivitas siswa

$$
\begin{aligned}
& \mathbf{P A}=\frac{\sum \mathrm{A}}{\mathrm{TA}} \times \mathbf{1 0 0 \%} \quad \text { (Purwanto, 2004: 132) } \\
& \text { Analisis keberhasilan tes } \\
& \mathrm{P}=\frac{\text { a yang tuntas belajar }}{\text { iswa keseluruhan }} \times 100 \% \text { (Arikunto. 2006:236) }
\end{aligned}
$$

Siswa dikatakan tuntas belajar secara individu jika siswa tersebut memperoleh skor hasil tes minimal 70, sedangkan ketuntasan belajar siswa secara klasikal paling sedikit $80 \%$ siswa tersebut tuntas belajar secara individu.

\section{HASIL}

\section{Aktifitas Siswa}

Aktivitas siswa pada siklus I belum sesuai dengan harapan yang diinginkan, karena masih banyak siswa yang ramai dan bicara dengan temannya ada juga yang diam dan main kertas, selain itu dalam mengidentifikai masalah siswa masih bingung terhadap demonstrasi yang dilakukan oleh guru. Dalam menanyakan hal yang kurang jelas dan mengungkapkan pendapatnya ataupun menanggapi penjelasan dan pertanyaan guru hanya sebagian siswa saja yang lainnya hanya diam dan belum memiliki keberanian dalam bertanya ataupun menanggapinya. Dalam mendiskusikan tugas dan mempresentasikan hasil kelompok, hanya sebagian siswa saja yang aktif. Siswa juga belum terbiasa menyimpulkan materi sehingga ketika menyimpulkan siswa masih bingung.

Untuk mengatasi masalah tersebut, maka siswa harus dilatih lagi untuk aktif dalam pembelajaran agar siswa lebih percaya diri dalam mengerjakan soal secara individu, dan yang terpenting pada saat mengemukakan pendapat dan mengkomunikasikan hasil kerja di depan kelas.

Aktivitas siswa pada siklus II mengalami peningkatan, Hal ini dapat terjadi karena penerapan model pembelajaran Quantum Learning yang dipakai pada siswa berjalan sesuai dengan yang diharapkan. Sehingga dapat dikatakan bahwa pembelajaran dengan mengunakan model Quantum Learning mampu meningkatkan aktivitas siswa di SDN Payungrejo Kutorejo Kabupaten Mojokerto.

\section{Aktifitas Guru}

Aktivitas guru pada siklus I masih banyak kekurangan, diantaranya ketika menyampaikan materi guru tergesa-gesa. Guru dianggap kurang mampu mengelola kelas karena ada beberapa siswa yang ramai, bercanda dan mengganggu teman yang lain saat diskusi berlangsung. Serta pengelolaan waktu kurang diperhatikan, sehingga waktu yang dibutuhkan setiap tahap pembelajaran yang sesuai dengan RPP yang dibuat dilakukan tidak seimbang. 
Aktivitas guru mengajar pada siklus II mengalami peningkatan, seluruh kegiatan dalam proses belajar mengajar sudah dapat dilaksanakan dengan baik, terlihat dari lembar pengelolaan pembelajaran siklus II. Pada lembar tersebut setiap lembar kegiatan pembelajaran memperoleh nilai 3 bahkan ada yang memperoleh nilai 4 . Nilai 3 dan 4 memiliki kategori baik dan sangat baik serta semua komponen yang direncanakan sudah dilaksanakan dengan baik. Rata-rata keseluruan komponen pada siklus I sebesar 2,875 dengan kategori kurang baik dan mengalami peningkatan pada siklus II sebesar 3,625 dengan kategori baik.

\section{Hasil Belajar Siswa}

Hasil belajar siswa pada siklus I dari 25 siswa ada 11 siswa yang tidak tuntas belajarnya karena belum mencapai nilai KKM, dan terdapat 14 siswa yang tuntas, dengan ketuntasan klasikal 56\%. Adapun faktor mempengaruhi hasil belajar pada siklus I adalah kurang mampu guru dalam mengelola pembelajaran yang sudah direncanakan serta ada beberapa siswa yang kurang mampu memahami pemecahan masalah yang diberikan karena kurang terbiasanya menerima metode yang digunakan oleh guru. Akibatnya hasil belajar yang diberikan pada siklus I kurang memuaskan. Sehingga penelitian ini dilanjutkan ke siklus II.

Hasil belajar pada siklus II dari 25 siswa ada 4 siswa yang tidak tuntas belajarnya karena belum mencapai nilai KKM, dan terdapat 21 siswa yang tuntas belajarnya, dengan ketuntasan klasikal 84\%. Hasil belajar pada siklus 2 ini mengalami peningkatan. Hasil ini disebabkan karena penggunaan metode pembelajaran yang digunakan siswa mampu menyelesaikan permasalahan yang berhubungan dengan materi yang diajarkan secara mendalam. Berdasarkan data yang diperoleh menunjukkan bahwa terjadi peningkatan pada hasil belajar siswa, baik secara individu maupun klasikal. Dengan demikian, pembelajaran dengan mengunakan model Quantum Learning telah berhasil dalam meningkatkan hasil belajar siswa

\section{KESIMPULAN}

Berdasarkan hasil penelitian dan pembahasan yang telah diuraikan dapat disimpulkan rata-rata aktifitas belajar pada siklus I yaitu sebesar 10,24 dengan ketuntasan klasikal $64 \%$ dan rata-rata hasil belajar pada siklus II mengalami kenaikan dan lebih tinggi dari siklus I yaitu sebesar 12,16 dengan ketuntasan klasikal 76\%. Sehingga penerapan pembelajaran menggunakan model Quantum Learning dapat meningkatkan aktifitas belajar siswa. Rata-rata hasil belajar pada siklus I yaitu sebesar 65,04 dengan ketuntasan klasikal $56 \%$ dan rata-rata hasil belajar pada siklus II mengalami kenaikan dan lebih tinggi dari siklus I yaitu sebesar 81,16 dengan ketuntasan klasikal 84\%. Sehingga penerapan pembelajaran menggunakan model Quantum Learning dapat meningkatkan hasil belajar siswa.

\section{SARAN}

Berdasarkan hasil penelitian yang telah dilakukan, saran yang dapat diberikan oleh peneliti, yaitu sebagai berikut: Sebelum melakukan proses belajar mengajar dengan menerapkan model pembelajaran Quantum Learning hendaknya guru mempersiapkan diri dengan baik, sehingga pada saat proses belajar mengajar 
tercipta suasana belajar yang menyenangkan, mengurangi kejenuhan dalam diri siswa, dan tercapai tujuan pembelajaran yang diharapkan.

\section{DAFTAR RUJUKAN}

Arikunto, Suharsini. 2006. Prosedur Penelitian Suatu Pendekatan Praktik. Jakarta: Rineka Cipta.

Arikunto, Suharsini, dkk. 2008. Penelitian Tindakan Kelas. Jakarta : Buni Aksara Cipta.

Bobbi DePorter \& Mike Hernacki. 2011. Quantum Learning. Bandung: Kaifa, Mizan Pustaka

DePorter Bobbi De Porter, Mark Reardom dan Sarah-Nouri Singer. 2010 Quantum Teaching: Mempraktikkan Quantum Learning di Ruang-ruang Kelas. Bandung: Kaifa, Mizan Pustaka

Dimyati dan Mujdiono. 2009. Belajar dan Pembelajaran. Jakarta: Rineka Cipta

Hudojo, Herman. 2005. Pengembangan Kurikulum dan Pembelajaran Matematika. Malang : Universitas Negeri Malang (UM PRESS).

Ihsan, Fuad. 2005. Dasar-dasar Kependidikan. Jakarta: Rineka Cipta.

Purwanto, N. 1988. Prinsip-prinsip dan Teknik Evaluasi Pengajaran. Bandung: Remaja Rosdakarya.

Widyastantyo, Hermawan. 2007. Penerapan Metode Quantum Learning Untuk Meningkatkan Hasil Belajar Mata Pelajaran IPA (SAINS) Bagi Siswa Kelas V SD Negeri Kebonsari Kabupaten Temanggung. Under Graduates thesis, Universitas Negeri Semarang. http://hermawanwidyastantyo. blogspot.com/1102402031(2007). (diakses tanggal 19 Juli 2014) 